\title{
Effect of Age and Genetic Groups on Growth Performance of Crossed Koekoek and Sasso Chickens
}

\author{
Bayesa Tolasa $^{1,}$, , Ahmad Seid ${ }^{2}$, Wasihun Hassen ${ }^{2}$, Mohamed Aliy ${ }^{2}$ \\ ${ }^{1}$ Department of Animal Science, Werabe University, Werabe, Ethiopia \\ ${ }^{2}$ Department of Animal Science, Jimma University, Jimma, Ethiopia
}

Email address:

bayeetola16@gmail.com (B. Tolasa)

*Corresponding author

\section{To cite this article:}

Bayesa Tolasa, Ahmad Seid, Wasihun Hassen, Mohamed Aliy. Effect of Age and Genetic Groups on Growth Performance of Crossed Koekoek and Sasso Chickens. Biochemistry and Molecular Biology. Vol. 5, No. 4, 2020, pp. 44-49. doi: 10.11648/j.bmb.20200504.11

Received: October 7, 2020; Accepted: October 22, 2020; Published: November 19, 2020

\begin{abstract}
This study was conducted to evaluate the effect of age and genetic groups on growth performance of crossed koekoek and sasso chickens. To fulfill this aim, a total of 360 randomly selected day-old-chicks (90 from each genetic group) were obtained from the hatchery of Jimma University College of Agriculture and Veterinary Medicine poultry farm. And then, the chicks were placed at brooder house in completely randomized design within three replicates. At the end of the brooding period, each group was transferred to grower's house. Data have been collected for sixteen weeks of age on the variables such as: body weight, daily weight gain, feed intake, feed conversion ratio and mortality. Finally, the collected data were entered in to a statistical analysis system (SAS, 2014, Version 9.3). The result revealed that Sasso (SS) had significantly $(\mathrm{P}<0.05)$ heavy body weight followed by crosses of Koekoek cockerels and Sasso pullets (KS crosses). In opposite, Koekoek (KK) parental breed was the least among others while crosses between Sasso cockerels and Koekoek pullets (SK crosses) were not far from KK. The values of mean and standard error for SS, KS, SK and KK were listed as follows: $983.00 \pm 12.55,883.00 \pm 11.65,820.00 \pm 11.60$ and $702.00 \pm 10.05$ at $8^{\text {th }}$ week, respectively. Among crosses, KS chicks gained significantly $(\mathrm{P}<0.05)$ higher daily body weight $(15.04 \pm 0.25)$ than the SK chicks $(13.96 \pm 0.20)$ at brooder phase. Further, the mean feed conversion ratio recorded for KS cross during brooding period were significantly $(p<0.05)$ higher than the mean feed conversion ratio recorded for SK cross with values (2.55 \pm 0.04 and $2.70 \pm 0.05)$, respectively. In summary, the resulting progenies from crosses of KK and SS performed better than both parental breeds, thus suggesting that is possible to be an encouraging factor for the poultry breeders to cross these two breeds (Koekoek male and Sasso female) to get hybrid vigor in growth performance.
\end{abstract}

Keywords: Chicken, Crossing, Genetic Group, Growth Performance, Koekoek, Sasso

\section{Introduction}

The total poultry population of Ethiopia is estimated to be 56.87 million as concerns to breed, $95.86 \%, 3.21 \%$ and $2.49 \%$ were indigenous, hybrid and exotic chickens, respectively [1]. These chickens provide a valuable source of food and cash income for most of rural households [2]. It also creates an employment opportunity for the youth, elders and women in the rural, peri-urban and urban areas [3]. However, factors such as lack of strong extension service, poor awareness of chicken producers towards improved husbandry practices, lack of inputs, disease outbreak, and unavailability of credit services, feed shortage and marketing system problems limit the productivity of chicken in the country [4].

In addition, lack of alternative chicken breeds that used dually for the purpose of both meat and egg production also another major problems which limit the supply and availability of chicken meat and egg in Ethiopia [2, 5]. With such types of reasons, after improving the chicken population of Ethiopia for nearly 67 years, the total number of hybrid chicken is estimated to be below $5 \%$ [1, 4]. Dual- purpose chicken such as koekoek and sasso breeds are mostly preferred for their egg and meat production as well as perform in village poultry production systems $[5,6]$. 
Koekoek chicken has best characteristics such as free ranging, adaptable to smallholder production systems, higher fertility and hatchability [7, 8]. On the other hand, sasso chickens is known by grow faster, delicious and tender meat, graze around the field and eating grass, corn, leaves, and other natural ingredients $[8,9]$. However, no any trial/study has been done on crossbreeding of these two chickens to create offspring that share the traits of both parent lineages and producing an animal with hybrid vigor. Therefore, the aim of the present study was designed to evaluate the effect of age and genetic groups on growth performance of crossed koekoek and sasso chickens.

\section{Materials and Methods}

\subsection{Experimental Site}

This study was conducted at Jimma University College of Agriculture and Veterinary Medicine (JUCAVM). The experimental site located at an altitude of 1700 meter and 357 kilometer to Southwest of the capital, Addis Ababa. The mean daily ambient temperature and relative humidity of the experimental site are $18^{\circ} \mathrm{C}$ and $65 \%$, respectively [10].

\subsection{Acquisition of Parental Lines and Mating Design}

The experiment was started by randomly taking 12 koekoek cocks, 12 Sasso cocks, 60 Sasso pullets and 60 koekoek pullets from available homogenous population in
JUCAVM poultry farm at 18 weeks of age. The cocks and pullets from each breed were randomly divided into two groups in sire position ( 1 male: 5 females). The first groups of 6 koekoek cocks were crossed with 30 Sasso pullets and the second groups of 6 koekoek cocks were mated with koekoek pullets. Similarly, the first groups of 6 Sasso cocks were crossed with 30 koekoek pullets and the second group of 6 Sasso cocks was mated with Sasso pullets.

The genetic groups were:

A. Koekoek (male) x Sasso (female): KS

B. Sasso (male) x Koekoek (female): SK

C. Koekoek (male) x Koekoek (female): KK

D. Sasso (male) x Sasso (female): SS

Mating was carried out in separate pens of house with a deep-litter housing system. Each pen was equipped with group laying nests, perches, feeder and drinker. During mating, chickens were offered with standard layer ration and water was offered adlibtum. Eggs were collected on daily basis for a period of 10 consecutive days and stored broadend up position in a cool dry place to ensure better air exchange until they set in the incubator. A total of 360 randomly selected day-old-chicks (90 from each genetic group) were used and allocated at JUCAVM brooder house to evaluate the performance of genetic groups. The chicks of each breed were randomly divided into 3 groups as replicates under the completely randomized design, so that there were 30 chicks in each replicate.

Table 1. Layout of the experiment.

\begin{tabular}{llll}
\hline Genetic Group & Number of chicks /Pen & Replication & Number of Chickens \\
\hline Koekoek (male) X Sasso (female) $\left(\mathrm{F}_{1}\right)$ & 30 & 3 & 90 \\
Sasso (male) X Koekoek (female) $\left(\mathrm{F}_{1}\right)$ & 30 & 3 & 90 \\
Koekoek (male) and Koekoek (female) & 30 & 3 & 90 \\
Sasso (male) x Sasso (female) & 30 & 3 & 90 \\
Total experimental chicks & & & 360 \\
\hline
\end{tabular}

\subsection{Management of Experimental Chickens}

All the experimental chickens were reared under uniform management conditions throughout the experimental period at JUCAVM poultry farm. The houses were cleaned and disinfected when the experiment was started and when the experimental chicken transferred to each types of house with formalin and potassium per Management. Drinker and a feeder were equipped to each types of house. The brooder house was preheated before on set of chicks for 48 hours.

All chicks were vaccinated at hatch and repeated on the $7^{\text {th }}$ and $21^{\text {st }}$ day of age and regularly vaccinated every month thereafter. For the initial period, day-old chicks were allocated in conventional wire cages equipped with drinkers and feeders, placed inside a conventional open-sided house. The house temperature was maintained at red infrared. Recommended amount of commercial ration (40g) starter fed was provided from hatch to $8^{\text {th }}$ weeks. Drinker and a feeder were cleaned two times a day up to the end of the experimental period. Orts were collected and weighed once a day. The death of chicks was recorded as mortality rate.
Houses were cleaned daily and water also available regularly. Lighting program was set to 24 hours brightness for the first 7 days (natural plus artificial). After that, artificial light period decreased by one hour per week.

\subsection{Data Collection and Type}

Record format was developed.

Body weight $(\mathrm{g})$ :- This was measured with the use of an electronic kitchen scale with maximum capacity of 20 kilogram at hatch, eight and sixteen ${ }^{\text {th }}$ weeks of ages. Chickens were weighed individually throughout the period.

Feed intake (g):- The feed left over was subtracted from feed given and the value divided by total number of chickens daily. It was calculated according to the formula below:

$$
\text { Feed intake }=\frac{\text { Feed given to the chicken }- \text { feed leftover }}{\text { Total number of chicken }}
$$

Daily weight gain (g):- The differences in body weight values between two consecutive measurements were divided by the number of days to obtain the daily weight gain. 
Daily weight gain $=\frac{\text { Recent body weight }- \text { Previous body weight }}{\text { Number of days }}$

Feed conversion ratio: - This was calculated as the ratio of daily weight gain to daily feed intake within each measurement period

$$
\mathrm{FCR}=\frac{\text { Daily feed intake }}{\text { Daily weight gain }}
$$

Mortality rate:- Mortality was the data which recorded on the death of chickens throughout the whole experimental period. This was calculated as the below formula:

$$
\text { Mortality rate }=\frac{\text { Number of death chickens } \times 100}{\text { Total number of chickens }}
$$

\subsection{Statistical Analysis}

All data gathered during the study period were recorded in Microsoft Excel 97-2003. Preliminary data analysis like homogeneity test, normality test were done before conducting the main data analysis. Quantitative data were subjected to General Linear Models (GLM) procedure of the Statistical Analysis System (SAS, 2014, Version 9.3). Tukey test was used to separate the means at $5 \%$ significance level.

The statistical model used for this study was:

$$
\mathrm{Y}_{\mathrm{ijk}}=\mu+\mathrm{Ai}+\mathrm{G}_{\mathrm{j}}+\mathrm{Ai} * \mathrm{Gj}+\mathrm{E}_{\mathrm{ijk}}
$$

Where:

$\mathrm{Y}_{\mathrm{ijk}}=$ performance of the $\mathrm{k}^{\text {th }}$ individual of the $\mathrm{j}^{\text {th }}$ genetic group at different $i^{\text {th }}$ ages

$\mu=$ Overall mean

$\mathrm{Ai}=$ Fixed effect of ages ( $\mathrm{i}=$ at hatch, 8 and $16^{\text {th }}$ week for body weight and $\mathrm{i}=$ at brooder phase and at grower phase for daily weight gain, feed intake and feed conversion ratio)

$\mathrm{G}_{\mathrm{i}}=$ Fixed effect of the genetic group $(\mathrm{j}=\mathrm{KK}, \mathrm{SS}, \mathrm{KS}$ and $\mathrm{SK}$ )

$\mathrm{AG}_{\mathrm{ij}}=$ Fixed effect of age* ${ }^{\text {genetic groups }}$

$\mathrm{EI}_{\mathrm{jkl}}=$ Residual error

\section{Results and Discussion}

\subsection{Body Weight}

The mean \pm se body weights of genetic groups under different ages were presented in table 2. There was no significantly difference between all genetic groups at hatch age. However, there were highly significant $(\mathrm{P}<0.05)$ differences among the four genetic groups at $8^{\text {th }}$ week body weight measured. The present result revealed that Sasso (SS) had significantly $(\mathrm{P}<0.05)$ heavy body weight followed by crosses of Koekoek cockerels and Sasso pullets (KS) and crosses between Sasso cockerels and Koekoek pullets (SK) then Koekoek (KK) with values of mean and standard error $(983.00 \pm 12.55,883.00 \pm 11.65,820.00 \pm 11.60$ and 702.00 $\pm 10.05)$ at $8^{\text {th }}$ week, respectively.

Moreover, there were highly significant differences between all genetic groups at $16^{\text {th }}$ week. Sasso parental breed was leading the groups throughout the period of study followed by both crosses of Koekoek cockerels and Sasso pullets (KS) and crosses between Sasso cockerels and Koekoek pullets (SK). In opposite, Koekoek breed was the least heavy breeds when compared to other genetic groups. The result was presented regarding genetic groups as follows for SS, KS, SK and KK with values $\left(2435.00^{\mathrm{a}} \pm 38.00\right.$, $2216.00^{\mathrm{b}} \pm 38.67, \quad 1975.00^{\mathrm{c}} \pm 38.07$ and $\left.1829.00^{\mathrm{c}} \pm 38.90\right)$, respectively. This significant difference $(\mathrm{P}<0.05)$ suggested that genes found only on allosome chromosomes might affect body weight at 8 and $16^{\text {th }}$ week.

The present result was higher than the result reported by Basant et al. [11] who reported that there was no significant difference between Rhode Island Red and Fayomi reciprocal crosses for average body weight at $16^{\text {th }}$ weeks of age $(1548 \mathrm{~g}$ for cross between Rhode Island Red cockerels and Fayoumi pullets and 1601gram for Fayoumi cockerels and Rhode Island Red pullets) in Egypt. However, it is in line with the result of Wondmeneh et al. [6] who reported that the body weight of Koekoek was 1802 gram at $16^{\text {th }}$ weeks of age, in

\begin{tabular}{|c|c|c|c|}
\hline Number & Genetic groups & Age & Body weight (g) \\
\hline 1 & $\begin{array}{l}\text { Koekoek cockerels crossed with Koekoek pullets } \\
(\mathrm{N}=90) \text { (pure KK) }\end{array}$ & $\begin{array}{l}\text { At hatch } \\
\text { At } 8^{\text {th }} \text { week } \\
\text { At } 16^{\text {th }} \text { week }\end{array}$ & $\begin{array}{l}36.52 \pm 0.86^{\text {ns }} \\
702.00^{d} \pm 10.05^{* \ldots} \\
1829.00^{\mathrm{c}} \pm 38.90^{*}\end{array}$ \\
\hline 2 & $\begin{array}{l}\text { Sasso cockerels crossed with Sasso pullets }(\mathrm{N}=90) \\
\text { (pure SS) }\end{array}$ & $\begin{array}{l}\text { At hatch } \\
\text { At } 8^{\text {th }} \text { week } \\
\text { At } 16^{\text {th }} \text { week }\end{array}$ & $\begin{array}{l}38.84 \pm 0.78^{\text {ns }} \\
983.00^{\mathrm{a}} \pm 12.55^{\ldots . .} \\
2435.00^{\mathrm{a}} \pm 38.00^{\circ .}\end{array}$ \\
\hline 3 & $\begin{array}{l}\text { Koekoek cockerels crossed with Sasso pullets }(\mathrm{N}=90) \\
\text { (cross KS) }\end{array}$ & $\begin{array}{l}\text { At hatch } \\
\text { At } 8^{\text {th }} \text { week } \\
\text { At } 16^{\text {th }} \text { week }\end{array}$ & $\begin{array}{l}40.54 \pm 0.80^{\text {ns }} \ldots \\
883.00^{\mathrm{b}} \pm 11.65^{\cdots} \cdots \\
2216.00^{\mathrm{b}} \pm 38.67^{\ldots}\end{array}$ \\
\hline 4 & $\begin{array}{l}\text { Sasso cockerels crossed with Koekoek pullets }(\mathrm{N}=90) \\
\text { (cross SK) }\end{array}$ & $\begin{array}{l}\text { At hatch } \\
\text { At } 8^{\text {th }} \text { week } \\
\text { At } 16^{\text {th }} \text { week }\end{array}$ & $\begin{array}{l}37.87 \pm 0.84^{\text {ns }} \ldots \\
820.00^{\circ} \pm 11.60^{\ldots} \ldots \\
1975.00^{\mathrm{c}} \pm 38.07^{\cdots}\end{array}$ \\
\hline
\end{tabular}
Debrezeit agricultural research center, Ethiopia.

Table 2. Mean \pm se body weights of genetic groups under different ages.

(a-d)=Means within a column with no common superscripts differ significantly $(\mathrm{p}<0.001),{ }^{*} \mathrm{P} \leq 0.05, * * \mathrm{P} \leq 0.01, * * * \mathrm{P} \leq 0.001$, ns: not significant, $\mathrm{SE}=$ standard error and $\mathrm{N}=$ Number of observation, $\mathrm{g}=\mathrm{gram}$.

\subsection{Daily Weight Gain}

Average daily weight gains of four genetic groups were presented in table 3. Although there were significant differences between genetic groups concerning daily weight gain no difference between two reciprocal crosses. KS chicks 
gained significantly $(\mathrm{P}<0.05)$ higher daily body weight (15.04) than the SK chicks (13.96). This difference between the two cross population suggested that sex -linked genes might affect body weight gain due to the reciprocal crossing. Similarly, Basant et al. [11] reported that there was no significant difference between Rhode Island Red and Fayomi reciprocal crosses for average daily body weight gain $(7.37 \mathrm{~g}$ for cross between Rhode Island Red cockerels and Fayoumi pullets and 7.62 for Fayoumi cockerels and Rhode Island Red pullets). In addition, both crosses (KS and SK) chicks gained higher daily body weight than KK breed (11.87) while lower than SS breed (16.85) in current study. Study indicated that Koekoek chicken required lower feed for a unit of gain in body weight [6]. Moreover, the current result were in line with the result of Amao [12] who reported that there was significant difference between Rhode Island Red and Naked neck for average daily body weight gain (13.50 for cross between Rhode Island Red cockerels and Naked neck pullets and 13.39 for Naked neck cockerels and Rhode Island Red pullets). Similarly, different authors [13-15] confirmed that the better performance of crosses.

Table 3. Mean \pm se daily weight gain of genetic groups under different ages.

\begin{tabular}{|c|c|c|c|}
\hline Number & Genetic groups & Age by phase & Daily weight gain (g) \\
\hline 1 & Koekoek cockerels crossed with Koekoek pullets $(\mathrm{N}=90)$ (pure KK) & $\begin{array}{l}\text { At brooder phase }\left(1-8^{\text {th }} \text { week }\right) \\
\text { At grower phase }\left(8-16^{\text {th }} \text { week }\right)\end{array}$ & $\begin{array}{l}11.87^{\mathrm{c}} \pm 0.05^{\circ} \\
20.00^{\mathrm{b}} \pm 0.90^{\circ}\end{array}$ \\
\hline 2 & Sasso cockerels crossed with Sasso pullets $(\mathrm{N}=90)$ (pure SS) & $\begin{array}{l}\text { At brooder phase }\left(1-8^{\text {th }} \text { week }\right) \\
\text { At grower phase }\left(8-16^{\text {th }} \text { week }\right)\end{array}$ & $\begin{array}{l}16.85^{\mathrm{a}} \pm 0.15^{\circ *} \\
26.00^{\mathrm{a}} \pm 0.70^{\cdots}\end{array}$ \\
\hline 3 & Koekoek cockerels crossed with Sasso pullets $(\mathrm{N}=90)$ (cross KS) & $\begin{array}{l}\text { At brooder phase }\left(1-8^{\text {th }} \text { week }\right) \\
\text { At grower phase }\left(8-16^{\text {th }} \text { week }\right)\end{array}$ & $\begin{array}{l}15.04^{\mathrm{b}} \pm 0.25^{\circ} \\
24.00^{\mathrm{a}} \pm 0.71^{\cdots}\end{array}$ \\
\hline 4 & Sasso cockerels crossed with Koekoek pullets $(\mathrm{N}=90)$ (cross SK) & $\begin{array}{l}\text { At brooder phase }\left(1-8^{\text {th }} \text { week }\right) \\
\text { At grower phase }\left(8-16^{\text {th }} \text { week }\right)\end{array}$ & $\begin{array}{l}13.96^{\mathrm{b}} \pm 0.20^{\circ} \\
20.60^{\mathrm{b}} \pm 0.68^{* * * *}\end{array}$ \\
\hline
\end{tabular}

(a-d)=Means within a column with no common superscripts differ significantly $(\mathrm{p}<0.001){ }^{*} \mathrm{P} \leq 0.05, * * \mathrm{P} \leq 0.01, *^{* *} \mathrm{P} \leq 0.001$, ns: not significant, $\mathrm{SE}=$ standard error and $\mathrm{N}=$ Number of observation, $\mathrm{g}=\mathrm{gram}$.

\subsection{Feed Intake and Feed Conversion Ratio}

The average feed intake and feed conversion ratio of experimental chicks were presented in table 4. There was significant difference between KK chicks, SS chicks and reciprocal crosses for feed intake at brooding phase. However, there was no significant difference $(\mathrm{P}<0.05)$ between the two cross chicks. Chicks of SS breed consumed more amount of ration (40.15) flowed by the two crosses (38.38 for KS) and 37.8 for SK) and KK breed chicks (34.45). The non-significant difference between the two cross population suggested that there is no effect of reciprocal crossing on feed intake. The present result was in comparable with the result of Jeremiah et al. [16] who reported that the frizzle feathered (40.10) and the both cross in their mean feed intake values (43.50 and 44.61), respectively while naked $\operatorname{neck}(37.80)$ chicken had the least feed intake(in gram) in Nigeria.

Further, there was significant difference between KK chicks, SS chicks and reciprocal crosses for feed conversion ratio. SS chicks had the best feed conversion ratio followed by KS chicks but, the KK chicks had the poorest feed conversion ratio. SS chicks had significantly $(\mathrm{P}<0.05)$ better feed conversion ratio $(2.38 \mathrm{~g})$ than $\mathrm{KK}$ chicks $(2.90)$ and $\mathrm{KS}$ cross had better values (2.55) than SK cross (2.70). Significant $(\mathrm{P}<0.05)$ difference in feed intake and feed conversion ratio were reported by Amao [12] who reported that Rhode Island Red consumed more amount of ration than their crosses and naked neck breed. In contrary, the result of Salo and Ayorinde [17] revealed that the crossbreds have significantly $(\mathrm{P}<0.05)$ higher feed intake and feed conversion ratio than the pure bred of Fulani Ecotype and dominant black chicken in Nigeria. The present result was higher than the result of Wondmeneh et al. [6] who reported that feed conversion ratio for Sasso breed with the values of 6.45 . Moreover, Aman et al. [9] reported that Sasso chicken consume more feed than the indigenous chicken in Areka, Southern Nation Nationalities and People, Ethiopia. Similarly, Razuki and AL-Shaheen [18] reported significant $(\mathrm{P}<0.05)$ differences between local breeds for feed conversion ratio from abroad.

Table 4. Mean \pm se average feed intake and feed conversion ratio of genetic groups under different ages.

\begin{tabular}{|c|c|c|c|c|}
\hline Number & Genetic groups & Age by phase & Feed intake & Feed conversion ratio \\
\hline \multirow{2}{*}{1} & \multirow{2}{*}{$\begin{array}{l}\text { Koekoek cockerels crossed with Koekoek pullets } \\
(\mathrm{N}=90) \text { (pure KK) }\end{array}$} & At brooder phase (1-8 ${ }^{\text {th }}$ week $)$ & $34.45^{\mathrm{c}} \pm 3.46^{\circ \mathrm{*}}$ & $2.90^{\mathrm{a}} \pm 0.05^{\mathrm{*a}}$ \\
\hline & & At grower phase ( $8-16^{\text {th }}$ week $)$ & $77.50 \pm 0.86^{\mathrm{ns}}$ & $3.90^{\mathrm{a}} \pm 0.09^{\circ}$ \\
\hline \multirow{2}{*}{2} & \multirow{2}{*}{$\begin{array}{l}\text { Sasso cockerels crossed with Sasso pullets }(\mathrm{N}=90) \\
\text { (pure SS) }\end{array}$} & At brooder phase (1- $8^{\text {th }}$ week $)$ & $40.15^{\mathrm{a}} \pm 3.48^{* \bullet}$ & $2.38^{\mathrm{c}} \pm 0.02^{\mathrm{*}}$ \\
\hline & & At grower phase (8-16 $6^{\text {th }}$ week $)$ & $81.50 \pm 0.8^{\text {ns }}$ & $3.00^{\mathrm{b}} \pm 0.08^{\prime \prime}$ \\
\hline \multirow{2}{*}{3} & \multirow{2}{*}{$\begin{array}{l}\text { Koekoek cockerels crossed with Sasso pullets } \\
(\mathrm{N}=90) \text { (cross KS) }\end{array}$} & At brooder phase $\left(1-8^{\text {th }}\right.$ week $)$ & $38.38^{\mathrm{ab}} \pm 3.42^{* *}$ & $2.55^{\mathrm{bc}} \pm 0.04^{\circ "}$ \\
\hline & & At grower phase (8-16 $6^{\text {th }}$ week $)$ & $79.50 \pm 0.76^{\mathrm{ns}}$ & $3.30^{\mathrm{b}} \pm 0.05^{\mathrm{\prime}}$ \\
\hline \multirow{2}{*}{4} & \multirow{2}{*}{$\begin{array}{l}\text { Sasso cockerels crossed with Koekoek pullets } \\
(\mathrm{N}=90) \text { (cross } \mathrm{SK})\end{array}$} & At brooder phase $\left(1-8^{\text {th }}\right.$ week $)$ & $37.80^{\mathrm{b}} \pm 3.46^{* *}$ & $2.70^{\mathrm{ab}} \pm 0.05^{\circ "}$ \\
\hline & & At grower phase (8-16 $6^{\text {th }}$ week) & $79.50 \pm 0.79^{\mathrm{ns}}$ & $3.86^{\mathrm{a}} \pm 0.04^{*}$ \\
\hline
\end{tabular}

(a-d)=Means within a column with no common superscripts differ significantly $(\mathrm{p}<0.001),{ }^{*} \mathrm{P} \leq 0.05, * * \mathrm{P} \leq 0.01, * * * \mathrm{P} \leq 0.001$, ns: not significant, $\mathrm{SE}=$ standard error and $\mathrm{N}=$ Number of observation. 


\subsection{Mortality Rate}

The mortality rate of brooder and growers were presented in table 5. The SS brooder among genetic groups had high mortality rate $(6.53 \%)$. However, crossing of KK with SS (KS and SK cross) were being increased in survival rate with the values of $1.22 \%$ and $2.11 \%$, respectively. Chickens mortality up to 8 weeks of age ranged from $4.3-5.3 \%$ for Rhode Island Red and from $4.3-5.7 \%$ for Fayoumi in central Oromiya [7].
Similarly, differences in mortality rate of sasso and koekoek breeds were reported [8]. KK growers had significantly the highest mortality rate $(8.11 \%)$ than other three genetic groups (1.23\% for KS, $3.15 \%$ for SS and $3.85 \%$ for SK). the mortality rate of Koekoek breed was significantly lower than Sasso breed in Ethiopia [6, 8]. The major reason why mortality rate was being high may be due to poor management system and diseases prevalent in the most parts of the country $[4,19]$.

Table 5. Mean \pm se mortality rate.

\begin{tabular}{|c|c|c|c|}
\hline Number & Genetic groups & Age by phase & Mortality rate \\
\hline \multirow{2}{*}{1} & \multirow{2}{*}{ Koekoek cockerels crossed with Koekoek pullets $(\mathrm{N}=90)$ (pure $\mathrm{KK})$} & At brooder phase $\left(1-8^{\text {th }}\right.$ week $)$ & $4.51^{\mathrm{b}} \pm 0.16^{* *}$ \\
\hline & & At grower phase $\left(8-16^{\text {th }}\right.$ week $)$ & $8.11^{\mathrm{a}} \pm 0.59^{* *}$ \\
\hline \multirow{2}{*}{2} & \multirow{2}{*}{ Sasso cockerels crossed with Sasso pullets $(\mathrm{N}=90)$ (pure $\mathrm{SS})$} & At brooder phase $\left(1-8^{\text {th }}\right.$ week $)$ & $6.53^{\mathrm{c}} \pm 0.21^{* *}$ \\
\hline & & At grower phase $\left(8-16^{\text {th }}\right.$ week $)$ & $3.15^{\mathrm{b}} \pm 0.63^{* *}$ \\
\hline \multirow{2}{*}{3} & \multirow{2}{*}{ Koekoek cockerels crossed with Sasso pullets $(\mathrm{N}=90)$ (cross KS) } & At brooder phase $\left(1-8^{\text {th }}\right.$ week $)$ & $1.22^{\mathrm{a}} \pm 0.23^{* *}$ \\
\hline & & At grower phase $\left(8-16^{\text {th }}\right.$ week $)$ & $1.23^{\mathrm{b}} \pm 0.62^{* *}$ \\
\hline 4 & Sasso cockerels crossed with Koekoek pullets $(\mathrm{N}=90)$ (cross SK) & At grower phase $\left(8-16^{\text {th }}\right.$ week $)$ & $3.85^{\mathrm{b}} \pm 0.64^{* *}$ \\
\hline
\end{tabular}

$(\mathrm{a}-\mathrm{d})=$ Means within a column with no common superscripts differ significantly $(\mathrm{p}<0.001), \mathrm{P} \leq 0.05, * * \mathrm{P} \leq 0.01$, ns: not significant, $\mathrm{SE}=$ standard error and $\mathrm{N}=$ Number of observation.

\section{Conclusion}

The present study was started by crossing Koekoek and Sasso chicken to evaluate the effect of ages and genetic groups on growth performances. The result indicated that KS cross was better than SK cross in terms of body weight, daily weight gain, feed intake and feed conversion ratio during both brooding and growing period. This cross was almost similar with Sasso breed that had better in former traits. Therefore, the current result may be an encouraging factor for the poultry breeders to cross these two breeds (Koekoek male and Sasso female) to get hybrid vigor in growth traits. Generally, it can be concluded that the resulting progenies from crosses of KK and SS (KS and SK crosses) performed better in terms of growth characteristic than the KK breed and lesser than SS breed. Thus, it is recommended that Koekoek male and Sasso female (KS cross) may be encouraged for the poultry breeders to get hybrid vigor in growth performance.

\section{Conflict of Interest}

The authors have declared that no conflict of interest.

\section{References}

[1] CSA. Agricultural Sample Survey. 2017. Volume II report on livestock and livestock characteristics (private peasant holdings). Central Statistical Agency (CSA): Addis Ababa, Ethiopia; 2017; 2: 584-585.

[2] Alemayehu G and Negasi A. Characterization of scavenging and intensive chicken production system in Lume District, East Showa Zone, Oromia Regional State, Ethiopia. Int. J. of
Livest. Prod; 2020; $11 \quad$ (1): $8-20$. DOI: 10.5897/IJLP2018.0569/.

http://www.academicjournals.org/IJLP.

[3] Abraham, L. and Yayneshet, T. Performance of exotic and indigenous poultry breeds managed by smallholder farmers in northern Ethiopia. Livestock Research for Rural Development; $2010 ; \quad 4$ : $13-16$. http://www.lrrd.org/lrrd22/7/leml22133.htm.

[4] Ahmed. M. Major Constraints and Health Management of Village Poultry Production in Ethiopia: Review School of Veterinary Medicine, Jimma University, Jimma, Ethiopia, International Journal of Research studies in Microbiology and Biotechnology; 2018; $\quad 4$ : 1-10 http://dx.doi.org/10.20431/2454-9428.0401001.

[5] Bekele, F., Ådnøy, T., Gjøen, H. M., Kathle, J., Girma, A. Production performance of dual purpose crosses of two indigenous with two exotic chicken breeds in sub-tropical environment. Int. J. Poultry Sci; 2010; 9: 702-710.

[6] Wondmeneh E E. H. Van der Waaij, H. M. J. Udo, D. Tadelle and J. A. M Van Arendonk. Village poultry production system: Perception of farmers and simulation of impacts of interventions. African Journal of Agricultural Research; 2016; 11: 2075-2081. DOI: 10.5897/AJAR2015.10493/http://www.academicjournals.org/ AJAR/.

[7] Geleta, T., Leta, S. and Bekana, E. Production performance of Fayoumi chickens under intensive management condition of Adami Tulu research center. Int. J. Livest. Prod; 2013; 4:172-176. http:/www.academicjournals.org/IJLP.

[8] Wondmeneh, E., Dawud, I. and Adey, M. Comparative evaluation of fertility and hatchability of Horro, Fayoumi, Lohmann Silver and Potchefstroom Potchefstroom koekoek breeds of chicken. Asian Journal of Poultry Science; 2011; 5: 124-129. 
[9] Aman G, Bangu B, Bereket Z, Desta G, Abiti T, 2017. Production performance of Sasso (distributed by ethio chicken private poultry farms) and Bovans brown chickens breed under village production system in three agro- ecologies of Southern Nations, Nationalities, and Peoples' Regional State (SNNPR), Ethiopia. Int. J. Livest. Prod; 8: 145-157. DOI: 10.5897/IJLP2017.0391/http://www.academicjournals.org/IJL $\mathrm{P}$.

[10] Solomon D. Egg production performance of local and White Leghorn hens under intensive and rural household conditions in Ethiopia. Livestock Research for Rural Development; 2008; 16: 8-9. ftp://ftp.fao.org/docrep/fao/011/ai320e/ai320e00.pdf.

[11] Basant, M. N. Shafik; El-Bayomi, Kh. M.; Sosa, G. A. and Osman, A. M. R. Effect of Crossing Fayoumi and Rhode Island Red on Growth Performance, Egg and Reproductive Traits Under Egyptian Conditions. Benha Veterinary Medical Journal; 2013; 24: 11-18.

[12] Amao, S.R. Effect of Crossing Fulani Ecotype with Rhode Island Red chickens on growth performance, egg and reproductive traits under Southern Guinea Savanna region of Nigeria. Journal of Animal and Verinary Science; 2017; 4: 14-18. http://www.openscienceonline.com/journal/javs.

[13] Tamir S, Moges, Y, Tilahun, H. Determinants of adoption of exotic poultry breeds among smallholder poultry producers in North Western Amahara Region, Ethiopia. Global Sci Res J; 2015; 3: 162-168. Link: https://bit.ly/2O0k6fE.

[14] Khawaja, T., Khan, S. H., Mukhtar, N., Parveen, A. and Fareed, G. Production performance, egg quality and biochemical parameters of three way crossbred chickens with reciprocal F1 crossbred chickens in sub-tropical environment. Italian Journal of Animal Science; 2013; 12: 127-132.

[15] Hermiz, H. N., K. A. Abas, A. M. Ahmed, T. R. Al-Khatib, Sh. M. Amin and D. A. Hamad. 2014. Effect of genetic lines and season on body weights of chicks. Recent Advances in Biomedical and Chemical Engineering and Materials Science; 2014; 1: 15-17 http://www.lrrd.org/lrrd16/2/deme1602.htm.

[16] Jeremiah M. I. Nwenya, E. P. Nwakpu, R. N. Nwose, K. P. Ogbuagu. Performance and Heterosis of Indigenous Chicken Crossbreed (Naked Neck x Frizzled Feather) In the Humid Tropics. Journal of Poultry Research; 2017; 14: 07-11.

[17] Sola-Ojo, F. E and Ayorinde, K. L. Evaluation of reproductive performance and egg quality traits in progenies of Dominant Black strain crossed with Fulani Ecotype Chicken. Journal of Agricultural Science; 2011; 3: 259-265.

[18] Razuki, W. M. and S. A. AL-Shaheen. Use of full diallel Cross to estimate crossbreeding effects in laying chickens. International Journal of Poultry Science; 2011; 10: 197-204.

[19] Yonas K, Sandip B, Mestawet T and Mohammed B. Urban poultry production systems and constraints of local and exotic chickens reared in Yirgalem and Hawassa Towns, Ethiopia, Int. J. Livest. Prod; 2019; 10: 62-69. DOI: 10.5897/IJLP2018.0540/http://www.academicjournals.org/IJL P. 